\title{
Vimentin expression in benign and malignant breast epithelium
}

\author{
M Heatley, C Whiteside, P Maxwell, P Toner
}

\begin{abstract}
Aims-To determine vimentin expression in epithelial cells in benign breast disease and malignant breast tumours; to assess the value of vimentin expression as a prognostic indicator in breast carcinoma.

Methods-Frozen and formalin fixed, paraffin wax embedded sections from 78 carcinomas, three phyllodes tumours, 19 fibroadenomas and 19 cases of fibrocystic disease were examined with a monoclonal antibody from the V9 clone. A correlation between vimentin expression and known prognostic indicators was sought in ductal carcinomas. The intracellular localisation of vimentin was examined in benign and malignant lesions.
\end{abstract}

Results-Vimentin expression was identified on frozen section in the cells of ductal (53\%), lobular (86\%), and mucinous $(33 \%)$ carcinomas and in the luminal epithelium of fibroadenomas (68\%), cases of fibrocystic disease $(47 \%)$, and a malignant phyllodes tumour. Formalin fixation reduced the percentage of carcinomas and cases of benign disease in which vimentin was detected. This reduction was more pronounced in fibroadenoma and fibrocystic disease than in ductal carcinoma. Associations were identified between vimentin expression as detected on frozen section and tumour grade, size, number of lymph nodes affected, oestrogen receptor content and growth fraction. Only the association with grade was significant $(p=0.045)$. There was no significant correlation between any of these prognostic variables and vimentin expression on paraffin wax sections. There was no difference in the intracellular localisation of vimentin staining between benign and malignant lesions, or between low and high grade ductal carcinomas.

Conclusion-There is some loss of vimentin immunoreactivity after formalin fixation. Vimentin expression does not assist in differentiating between benign and malignant breast disease, but is correlated with tumour grade in ductal carcinoma.

(F Clin Pathol 1993;46:441-445)

The cytoplasmic intermediate filament proteins which form part of the cytoskeleton have been categorised into five distinct classes that differ in their biochemical and antigenic properties. ${ }^{12}$ They are variably expressed in different cell types and in corresponding tumours. Cytokeratins are usually expressed in epithelial cells and carcinomas but mesenchymal cells, lymphomas, and non-muscular sarcomas express vimentin ${ }^{3-5}$; coexpression of vimentin and cytokeratin has, however, been described in several common epithelial tumours. ${ }^{6-14}$

Raymond and Leong ${ }^{15} 16$ have suggested that vimentin expression in breast tumours is an indicator of prognosis. ${ }^{15}$ In this study vimentin expression was examined in benign and malignant breast disease and an association was sought between vimentin expression and other prognostic indicators in cases of infiltrating ductal carcinoma. The intracellular localisation of vimentin was also studied, as Raymond and Leong ${ }^{15}$ found that the intracellular position of vimentin varied from benign and low grade malignant tumours to high grade malignancies. Both frozen sections and formalin fixed, paraffin wax sections are described, because although the immunoreactivity of intermediate filaments is best preserved on frozen section, ${ }^{213}$ most routine specimens are submitted in formalin based fixatives.

\section{Methods}

Fresh specimens of breast tissue, including lumpectomies and mastectomies for malignant conditions and local excisions for benign breast disease, were transported, on ice, to the laboratory. The diagnosis had already been established in all cases by fine needle aspiration. A portion of fresh tissue was excised from each case, snap frozen in precooled isopentane (Prolabo, Paris), and embedded in Cryoblock embedding medium (Anglia Scientific, Cambridge, England). Frozen sections were then cut at $5 \mu \mathrm{m}$ intervals on a Bright cryostat. Tissue from each case of breast carcinoma was also snap frozen for oestrogen receptor assay.

The specimen was fixed overnight in $10 \%$ formalin and the gross dissection completed next morning, when the dimensions of the lesion were measured. Paraffin wax sections $(5 \mu \mathrm{m})$ were cut from representative blocks. All lymph nodes identified were submitted for histological examination.

Vimentin (Dakopatts) was detected on cryostat sections at a dilution of 1 in 20 using the indirect peroxidase method and on paraf- 
Table 1 Proportion of cells reacting with antibody to vimentin on frozen section

\begin{tabular}{lllll}
\hline & \multicolumn{3}{l}{$\begin{array}{l}\text { Proportion of cells } \\
\text { reacting to antibody }\end{array}$} \\
\cline { 2 - 5 } & 0 & 1 & $2+$ & Total \\
\hline Ductal carcinoma all grades & $32(47 \%)$ & 26 & 10 & 68 \\
Fibroadenoma & $6(32 \%)$ & 10 & 3 & 19 \\
Fibrocystic disease & $10(53 \%)$ & 8 & 1 & 19 \\
Total benign breast disease & 16 & 18 & 4 & 38 \\
Lobular carcinoma & 1 & 6 & 0 & 7 \\
Mucinous carcinoma & 2 & 1 & 0 & 3 \\
Phyllodes tumour benign & 2 & 0 & 0 & 2 \\
Phyllodes tumour malignant & 0 & 1 & 0 & 1 \\
\hline
\end{tabular}

Table 2 Proportion of cells reacting with antibody to vimentin on paraffin wax sections

\begin{tabular}{lllll}
\hline & \multicolumn{3}{l}{$\begin{array}{l}\text { Proportion of cells } \\
\text { reacting to antibody }\end{array}$} \\
\cline { 2 - 5 } & 0 & 1 & $2+$ & Total \\
\hline Ductal carcinoma all grades & $36(54 \%)$ & 24 & 7 & 67 \\
Fibroadenoma & $17(89 \%)$ & 2 & 0 & 19 \\
Fibrocystic disease & $14(82 \%)$ & 3 & 0 & 17 \\
Total benign breast disease & 31 & 5 & 0 & 36 \\
Lobular carcinoma & 3 & 4 & 0 & 7 \\
Mucinous carcinoma & 2 & 1 & 0 & 3 \\
Phyllodes tumour benign & 2 & 0 & 0 & 2 \\
Phyllodes tumour malignant & 1 & 0 & 0 & 1 \\
\hline
\end{tabular}

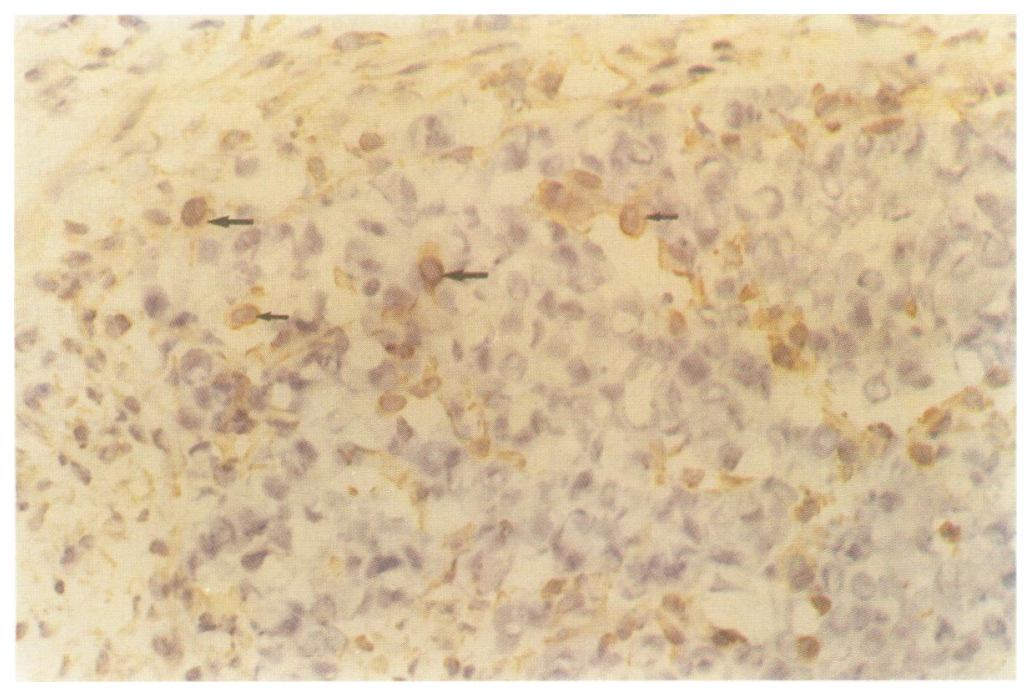

Figure 1 In this ductal breast carcinoma vimentin expression is detected in the stromal tissues of the breast and in occasional tumour cells. In most positive cells the staining is distributed diffusely in the cytoplasm (small arrows), although perinuclear staining (large arrows) is also seen in a few cells (frozen section).

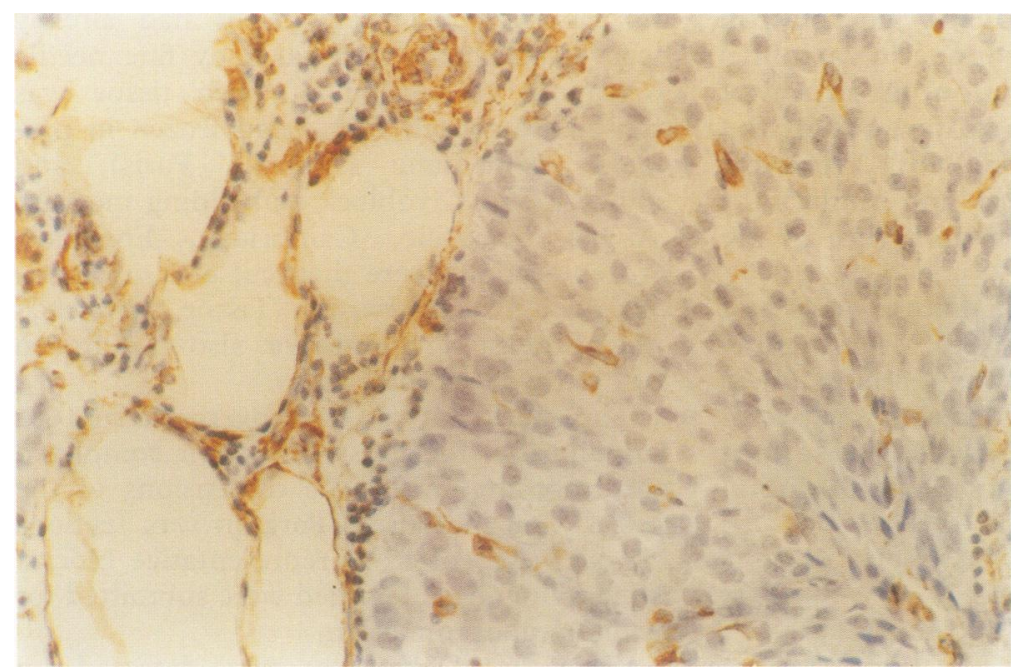

Figure 2 Vimentin expression in the same case examined in formalin fixed, paraffin wax embedded tissue. Once again occasional tumour cells react with the antibody to vimentin (paraffin wax section). fin wax sections with the same antibody at a dilution of 1 in 5 using the peroxidase avidin biotin complex method (Dakopatts). Cytokeratin expression was confirmed in all cases using the anti-cytokeratin antibodies $\mathrm{AE} 1$ and AE3 (ICN), each at a dilution of 1 in 50 .

The proportion of cells reacting with the anti-vimentin antibody was graded using a semiquantitative scale. If no staining was present in the epithelium the case was graded 0. Cases in which up to $25 \%$ of cells reacted positively were graded 1 and cases with $26 \%$ or more were graded 2. A formal count of the proportion of positively reacting cells was also performed. Five random areas were sampled using a graticule, the number of positive cells being expressed as a percentage of the total number of epithelial cells counted. There was good agreement between the two methods.

Vimentin expression was compared in a group of infiltrating ductal carcinomas and a benign group classified as fibrocystic disease. The infiltrating ductal carcinomas were also compared with a group of fibroadenomas and with all the benign lesions taken together. These statistical analyses were performed using the $\chi^{2}$ test. Cases of lobular carcinoma, phyllodes tumours (benign and malignant), and mucinous carcinoma were also studied, but their numbers were considered too small to justify statistical analysis. The intracellular localisation of vimentin was compared in benign and malignant disease and in low and high grade malignancies.

An association was sought between vimentin expression in the 68 infiltrating ductal (NOS) carcinomas and the following five known prognostic indicators.

Histological grade: This was assigned using Elston's ${ }^{17}$ modification of the Bloom and Richardson ${ }^{18}$ method. There was fair to good agreement when the tumour grade assigned to each tumour by two histopathologists was compared using Cohen's $\mathrm{K}$ test ${ }^{19}(\mathrm{~K}=0 \cdot 71)$. Maximum tumour diameter: This was measured on the gross specimen as described above.

Lymph node status: The number of lymph nodes with histological evidence of tumour was noted. To facilitate statistical analysis, the cases were divided according to size and the number of affected axillary lymph nodes, according to the TNM staging system. ${ }^{20}$ The proportion of vimentin positive and negative cases in each prognostic group was compared using the $\chi^{2}$ test. The association in tumour grade was examined with $\chi^{2}$ for trends. ${ }^{21}$

Oestrogen receptor content: This was assayed using the Abbot ER-EIA monoclonal kit (Abbot Laboratories, North Chicago, Illinois USA).

Growth fraction: 60 cases of infiltrating ductal carcinoma were stained with the indirect peroxidase technique using a murine monoclonal $\mathrm{Ki}-67$ antibody (Dakopatts) at a dilution of 1 in 25 . The growth fraction was the number of cells reacting with the $\mathrm{Ki}-67$ antibody expressed as a percentage of the total number of epithelial cells counted.

Fresh frozen tissue from 68 infiltrating 


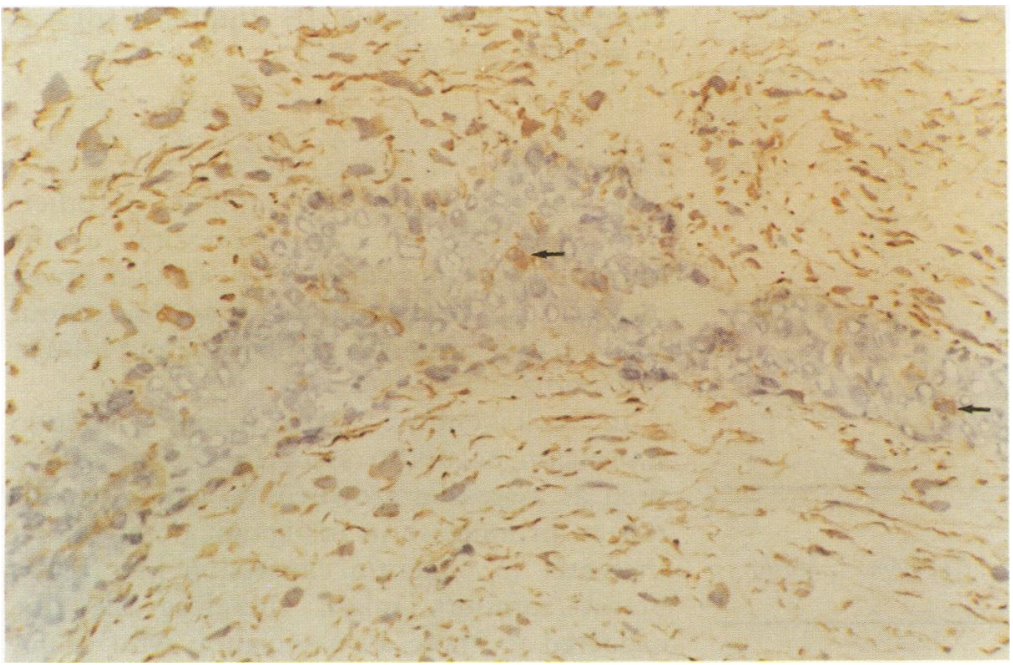

Figure 3 Reaction of the antibody to vimentin in a fibroadenoma. The V9 antibody stains the stroma and myoepithelium. A reaction in only occasional luminal epithelial cells is seen where it is distributed around the cell nuclei (arrows) (frozen section).

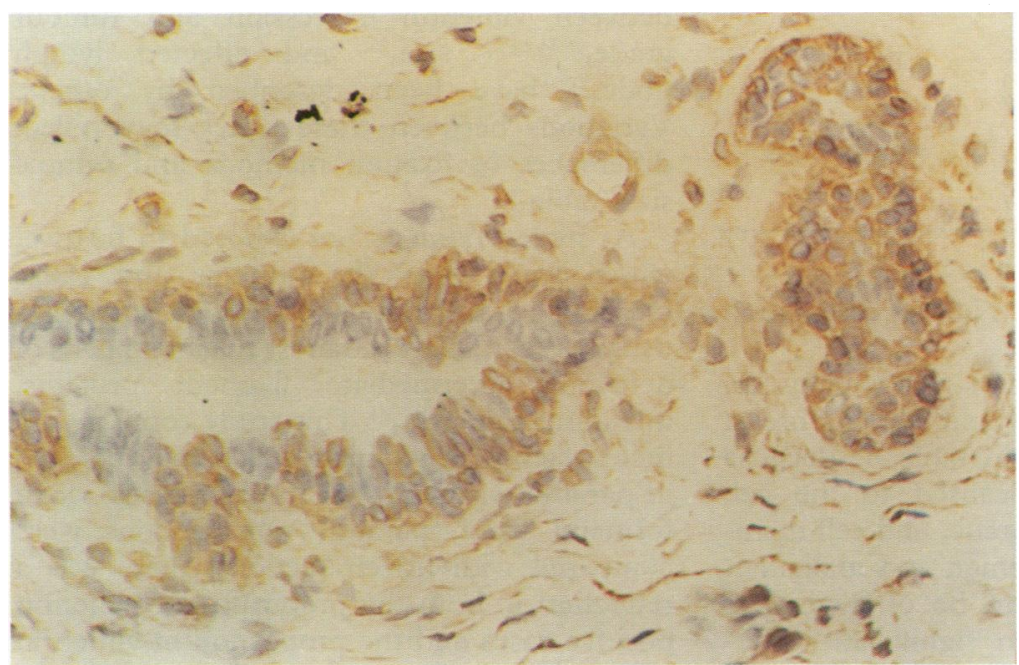

Figure 4 In this case of fibrocystic disease vimentin expression is detected in the stroma, myoepithelium, and occasional epithelial cells (frozen section).

ductal carcinomas, seven lobular carcinomas, three mucinous carcinomas, three phyllodes tumours (two benign and one malignant), 19 fibroadenomas and 19 cases of fibrocystic disease were available for study. Formalin fixed, paraffin wax embedded tissue was also available in all but one case, a ductal carcinoma.

\section{Results}

Cytokeratin expression was detected in up to

Table 3 Percentage of cases reacting positively with antibody to vimentin on frozen and paraffin wax section

\begin{tabular}{|c|c|c|}
\hline \multirow[b]{2}{*}{ Ductal carcinoma } & \multicolumn{2}{|c|}{ Percentage of cases reacting ( $95 \%$ confidence limits) } \\
\hline & Frozen section & Paraffin wax section \\
\hline $\begin{array}{l}\text { Ductal carcinoma } \\
\text { Fibroadenoma } \\
\text { Fibrocystic disease } \\
\text { Total benign breast disease } \\
\text { Lobular carcinoma } \\
\text { Mucinous carcinoma } \\
\text { Phyllodes tumour, benign } \\
\text { Phyllodes tumour, malignant }\end{array}$ & $\begin{array}{l}53 \%(40 \%, 65 \%) \\
68 \%(43 \%, 87 \%)^{\star \star \star \star} \\
47 \%(24 \%, 71 \%)^{\star \star \star \star} \\
58 \%(41 \%, 74 \%)^{\star \star \star \star} \\
85 \%(42 \%, 99 \%) \\
33 \%(1 \%, 91 \%) \\
100 \% \\
100 \%\end{array}$ & $\begin{array}{l}46 \%(34 \%, 59 \%) \\
11 \%(1 \cdot 3 \% 33 \%)^{\star} \\
18 \%(4 \%, 43 \%)^{\star \star} \\
14 \%(5 \%, 29 \%)^{\star \star \star} \\
57 \%(18 \%, 90 \%) \\
33 \%(1 \%, 91 \%) \\
0 \% \\
0 \%\end{array}$ \\
\hline $\left.\begin{array}{rl}\star{ }_{p} & <0.05 \\
\star \star \mathrm{p} & <0.01 \\
\star \star \star \star \mathrm{p} & <0.001 \\
\star \star \star \star \mathrm{p} & >0.05\end{array}\right\}$ & d with ductal carcinoma & \\
\hline
\end{tabular}

$100 \%$ of the epithelial cells in all cases of carcinoma, fibroadenoma, phyllodes tumour and fibrocystic disease. Cytokeratins were distributed diffusely in the cytoplasm in all lesions, with perinuclear and subplasmalemmal accentuation in a number of cases.

Vimentin was expressed in stromal connective tissues, in the walls of blood vessels, in nerves and in myoepithelial cells. Vimentin expression in benign and malignant epithelial cells is detailed in tables 1 and 2 . Vimentin was detected in cancer cells in ductal, lobular, and mucinous carcinoma and in the luminal epithelium of fibroadenoma, fibrocystic disease, and the malignant phyllodes tumour (figs 1-4), but not in the luminal epithelium of the two benign phyllodes tumours.

There was no significant difference in the proportion of malignant and benign conditions reacting for vimentin on frozen section (table 3). Vimentin expression was detected in fewer cases and in a smaller proportion of cells in formalin fixed material (figs 1 and 2). These reductions were greater in fibroadenoma and fibrocystic disease than in ductal carcinoma, resulting in a significant difference in the proportion of cases of carcinoma and benign breast disease in which epithelial cells reacted for vimentin on paraffin wax sections (table 3). There was no significant difference in vimentin expression between fibroadenoma and fibrocystic disease, in either frozen or paraffin wax sections.

Vimentin was detected on frozen section in 36 of 68 ductal carcinomas, increasing with tumour grade and the number of affected axillary lymph nodes. Vimentin expression was also more commonly seen on frozen sections in tumours over $2 \mathrm{~cm}$ in diameter (table 4). The only significant correlation was between tumour grade and vimentin expression on frozen section.

In paraffin wax sections vimentin was expressed in 31 cases, again increasing with tumour grade. Vimentin was more often detected in tumours affecting four or more axillary lymph nodes. In contrast with the findings on frozen section, vimentin was more often detected in tumours under $2 \mathrm{~cm}$ in diameter (table 5). None of these results on paraffin wax sections reached significance.

Oestrogen receptor content and growth fraction were compared with the actual percentage of vimentin, positive epithelial cells on frozen section, using Spearman's rank correlation coefficient (Rho). The mean concentration of oestrogen receptors in the cases of ductal carcinoma was $68.06 \mathrm{fmol} / \mathrm{pg}$ of cytosolic protein. The mean (SD) proportion of $\mathrm{Ki}-67$ positive cells in these cases was $10.58 \%(8.84 \%)$ and the median $9.69 \%$ $(\mathrm{min} / \mathrm{min}, \max / \max 0 \%, 60.5 \%)$. The percentage of vimentin positive tumour cells on frozen section showed a weak positive correlation with the concentration of oestrogen receptors. (Rho $=0.05 ; 95 \%$ confidence limits -0.23 and +0.33 ). There was also a weak positive correlation between the proportion of $\mathrm{Ki}-67$ and vimentin positive tumour cells on frozen section $(\mathrm{Rho}=0.214 ; 95 \%$ confidence 
Table 4 Vimentin expression, with prognostic indicators, in ductal carcinoma (frozen section)

\begin{tabular}{|c|c|c|c|c|c|}
\hline \multirow{2}{*}{$\begin{array}{l}\text { Infiltrating ductal } \\
\text { carcinoma }\end{array}$} & \multicolumn{5}{|c|}{ Vimentin expression } \\
\hline & 0 & 1 & 2 & & \\
\hline \multicolumn{6}{|l|}{ Tumour grade: } \\
\hline Grade I & 15 & 7 & 1 & 23 & $p=0.045$ \\
\hline Grade II & 14 & 12 & 6 & 32 & \\
\hline Grade III & 3 & 7 & 3 & 13 & \\
\hline \multicolumn{6}{|l|}{ Tumour size: } \\
\hline$<2 \mathrm{~cm}$ & 15 & 6 & 5 & 26 & $\mathrm{p}=0.38 ; \mathrm{NS}$ \\
\hline $2-5 \mathrm{~cm}$ & 14 & 16 & 5 & 35 & \\
\hline \multirow{2}{*}{\multicolumn{6}{|c|}{$\begin{array}{l}>5 \mathrm{~cm} \\
\text { Positive lymph nodes }\end{array}$}} \\
\hline & & & & & \\
\hline 0 & 14 & 6 & 5 & 25 & $p=0.29 ; N S$ \\
\hline $1-3$ & 7 & 9 & 3 & 19 & \\
\hline $4+$ & 2 & 5 & 0 & 7 & \\
\hline
\end{tabular}

Table 5 Vimentin expression, with prognostic indicators, in ductal carcinoma (paraffin wax section)

\begin{tabular}{|c|c|c|c|c|c|}
\hline \multirow{2}{*}{$\begin{array}{l}\text { Infiltrating ductal } \\
\text { carcinoma }\end{array}$} & \multicolumn{5}{|c|}{ Vimentin expression } \\
\hline & 0 & 1 & 2 & & \\
\hline \multicolumn{6}{|l|}{ Tumour grade: } \\
\hline Grade I & 13 & 8 & 2 & 23 & $p=0.71 ; N S$ \\
\hline Grade II & 17 & 11 & 4 & 32 & \\
\hline Grade III & 6 & 5 & 1 & 12 & \\
\hline \multicolumn{6}{|l|}{ Tumour size: } \\
\hline$<2 \mathrm{~cm}$ & 12 & 9 & 5 & 26 & $p=0.61 ; N S$ \\
\hline $2-5 \mathrm{~cm}$ & 20 & 12 & 2 & 34 & \\
\hline$>5 \mathrm{~cm}$ & 4 & 3 & 0 & 7 & \\
\hline \multicolumn{6}{|l|}{ Positive lymph nodes } \\
\hline 0 & 14 & 8 & 3 & 25 & $p=0.70 ; N S$ \\
\hline $1-3$ & 11 & 4 & 3 & 18 & \\
\hline $4+$ & 2 & 4 & 1 & 7 & \\
\hline
\end{tabular}

limits -0.04 and $+0 \cdot 44)$. Neither association reached significance.

The intracellular localisation of vimentin in ductal carcinoma (fig 1) and benign breast disease (fig 3 ) is shown in table 6 . Because vimentin was immunolocalised to the cell cytoplasm, nuclear membrane, and cell membrane in cases of both benign and malignant disease, this is unlikely to be of diagnostic assistance. There was no significant difference in the site of vimentin expression in ductal carcinoma, either when all three grades were compared $\left(\mathrm{df}=4, \chi^{2}=1.963, \mathrm{p}=0.73\right.$, NS) or when grades I and II combined were

Table 6 Intracellular location of vimentin expression in breast lesions

\begin{tabular}{llllc}
\hline Invasive ductal carcinoma & Cell membrane & $\begin{array}{l}\text { Cytoplasmic } \\
\text { subplasmalemmal }\end{array}$ & $\begin{array}{l}\text { Diffuse } \\
\text { cytoplasmic }\end{array}$ & Perinuclear \\
\hline Grade I & 0 & 0 & 5 & 3 \\
Grade II & 1 & 0 & 7 & 9 \\
Grade III & 0 & 0 & 6 & 5 \\
All grades & 1 & 0 & 18 & 17 \\
Fibroadenoma & 1 & 0 & 9 & 3 \\
Fibrocystic disease & 1 & 1 & 1 & 5 \\
Benign lesions & 2 & 1 & 10 & 8 \\
\hline
\end{tabular}

Table 7 Method of tissue preparation and proportion of ductal carcinomas in which tumour cells reacted with antibodies to vimentin in six series

\begin{tabular}{|c|c|c|c|}
\hline & Tissue preparation & $\begin{array}{l}\text { Proportion of cases } \\
\text { in which vimentin } \\
\text { was detected in } \\
\text { ductal carcinoma }\end{array}$ & $\begin{array}{l}\text { Number of cases of } \\
\text { infiltrating ductal } \\
\text { carcinoma (NOS) } \\
\text { studied }\end{array}$ \\
\hline This study & $\begin{array}{l}\text { Frozen section } \\
\text { Formalin fixation }\end{array}$ & $\begin{array}{l}36 / 68(53 \%) \\
31 / 67(46 \%)\end{array}$ & $\begin{array}{l}68 \\
67\end{array}$ \\
\hline Cattoretti et $a l^{28}$ & Frozen section & $49 / 196(25 \%)$ & 196 \\
\hline Domagala et $a l^{5}$ & $\begin{array}{l}\text { Fine needle aspiration } \\
\text { biopsy and ethanol fixation }\end{array}$ & $15 / 68(22 \%)$ & 68 \\
\hline Domagala et $a l^{6}$ & $\begin{array}{l}\text { Formalin fixed, paraffin } \\
\text { wax embedded tissue }\end{array}$ & $34 / 195(17 \%)$ & 195 \\
\hline Domagala et $a l^{7}$ & $\begin{array}{l}\text { Formalin fixed, } \\
\text { paraffin wax embedded }\end{array}$ & $35 / 214(16 \%)$ & 214 \\
\hline Raymond and Leong ${ }^{16}$ & $\begin{array}{l}\text { Microwave fixation, } \\
\text { paraffin wax embedded }\end{array}$ & $41 / 78(53 \%)$ & 78 \\
\hline
\end{tabular}

compared with grade III tumours $(\mathrm{df}=2$, $\left.\chi^{2}=0 \cdot 489, \mathrm{p}=0 \cdot 78, \mathrm{NS}\right)$.

\section{Discussion}

This study confirms the findings of others who identified vimentin expression in the luminal epithelium in cases of benign breast disease, ${ }^{15}$ phyllodes tumours, ${ }^{22}$ and in tumour cells in cases of ductal, mucinous, and lobular carcinoma. 151622

In cell culture experiments vimentin expression occurs in association with factors such as increased growth rate, which usually reflect an increase in malignant potential. ${ }^{23} 24$ Increases in vimentin expression in primary breast tumours might therefore also be expected to show an association with established clinical prognostic indicators, such as increases in tumour grade and size and increasing numbers of affected lymph nodes, as described in this study. Similar correlations between vimentin expression and tumour grade, ${ }^{15}{ }_{1625-27}$ size $^{28}$ and affected lymph nodes $^{27}$ have been described by others. Variations between these series may reflect differences in fixation methods and sample size (table 7).

As frozen tissue is not exposed to fixative, which could alter the proteins and cause masking of antigenic sites, frozen section is usually regarded as the most reliable means of detecting intermediate filament proteins, including vimentin. ${ }^{23}$ This study confirms the inconsistency of staining which may be seen in paraffin wax sections. In most cases, when formalin fixed, paraffin wax sections were compared with frozen sections, there was a reduction in both the proportion of vimentin positive cases and the proportion of vimentin positive cells. The apparent loss of vimentin immunoreactivity, probably due to loss of vimentin epitopes following formalin fixation, was more noticeable in benign than malignant lesions. As a result, differences in vimentin expression, which were significant but which were confined to paraffin wax sections, were detected between the two groups.

The occurrence of more positive reactions on paraffin wax section in grade I malignant tumours and in those of less than $2 \mathrm{~cm}$ in diameter seems at variance with the more general results and is not easily explained, although the proportion of vimentin positive cells in these cases was often less than $25 \%$. In some cases, distortion of the polypeptide structure of the antigen following formalin fixation and paraffin wax processing might have resulted in the artefactal exposure of epitopes to which non-specific antibody binding could occur. This might result in a proportion of false positive reactions. Whatever the explanation, it runs contrary to the overall experience of this study.

In the present study vimentin expression was positively correlated with oestrogen receptor concentration in ductal carcinoma, although Domagala et $a l^{25}$ and Raymond and Leong ${ }^{16}$ found a negative correlation. Like these authors, the present study found a posi- 
tive correlation between vimentin expression and tumour growth fractions.

Vimentin intermediate filaments in avian red blood cells form a perinuclear ring, from which filaments radiate throughout the cytoplasm to terminate on the cell membrane. ${ }^{29} 30$ This pattern would account for the perinuclear staining with anti-vimentin antibodies described by Raymond and Leong, ${ }^{15}$ with less intense staining in the adjacent cytoplasm in low grade carcinomas and benign breast disease. The loss of the perinuclear distribution of vimentin in high grade (grade III) carcinomas could represent a progressive disorganisation of the cytoskeleton.

The intracellular localisation of vimentin, however, does not differ sufficiently in benign and malignant breast disease to be of diagnostic value. The location of vimentin within cancer cells is also unlikely to assist in differentiating between high and low grade tumours. The absence of significant differences in intracellular localisation does not support the hypothesis that the distribution of vimentin intermediate filaments in tumour cells becomes progressively disordered with increasing tumour grade.

1 Fuchs E. Keratins as biochemical markers of epithelial differentiation. Trends Genet 1988;4:227-81.

2 Nagle RB. Intermediate filaments: A review of the basic biology. Am $f$ Surg Pathol 1988;12(Suppl 1);4-16.

3 Osborn M, Weber K. Biology of disease. Tumor diagnosis by intermediate filament typing: a novel tool for surgical pathology. Lab Invest 1983;48:372-93.

4 Domagala W, Lubinski J, Weber $\mathbf{K}$, Osborn $\mathbf{M}$. Intermediate filament typing of tumor cells in fine needle aspirates by means of monoclonal antibodies. Acta Cytol 1986;30:214-24.

5 Lehto VP, Miettinen M, Virtanen I. Antibodies to intermediate filaments in surgical pathology. Arch Geschwulst Forsch 1986;56:283-98.

6 Altmannsberger $M$, Dralle $H$, Weber $K$, Osborn $M$, Droese $M$. Intermediate filaments in cytological speciDroese $M$. Intermediate filaments in cytological speci-
mens of thyroid tumours. Diagn Cytopathol 1987;3: mens of

7 Buley ID, Gatter KC, Heryet A, Mason DY. Expression of intermediate filament proteins in normal and diseased thyroid glands. $\mathcal{f}$ Clin Pathol 1987;40:136-42.

8 Kawahara E, Ooi A, Oda Y, Katsuda S, Terahata S, Michigishi T. Papillary carcinoma of the thyroid gland with anaplastic transformation in the metastatic foci. An immunohistochemical study. Acta Pathol भpn 1986;36: 921-7.

9 Henzen-Logmans SC, Stel HV, Van Muijen GNP, Mullink H, Meijer CJLM. Expression of intermediate filament proteins in adrenal cortex and related tumours. Histopathology 1988;12:359-72.

10 Fleming S, Symes CE. The distribution of cytokeratin antigens in the kidney and in renal tumours. Histopathology 1987;11:157-70.
11 Pitz S, Moll R, Storkel S, Thoenes W. Expression of intermediate filament proteins in subtypes of renal cell carcinomas and in renal oncocytomas. Distinction of two classes of renal cell tumors. Lab Invest 1987;56:642-53.

12 Leong AS-Y, Gilham P, Milios J. Cytokeratin and vimentin intermediate filament proteins in benign and neoplastic prostatic epithelium. Histopathology 1988;13: 435-42.

13 Azumi N, Battifora $H$. The distribution of Vimentin and Keratin in epithelial and nonepithelial neoplasms. A comprehensive immunohistochemical study on formalin-and alcohol-fixed tumors. Am 7 Clin Pathol 1987; 88:286-96.

14 Ellis IO, Bell J, Ronan JE, Elston CW, Blamey RW. Immunocytochemical investigation of intermediate filament proteins and epithelial membrane antigen in spindle cell tumours of the breast. $f$ Pathol 1988;154: dle cell

15 Raymond WA, Leong AS-Y. Co-expression of cytokeratin and Vimentin intermediate filament proteins in benign and neoplastic breast epithelium. If Pathol 1989;157: 299-306.

16 Raymond A, Leong A S-Y. Vimentin-A new prognostic parameter in breast carcinoma? $f$ Pathol 1989;158: 107-14.

17 Elston CW. The assessment of histological differentiation in breast cancer. Aust NZ F Surg 1984;54:11-15.

18 Bloom HJG, Richardson WW. Histological grading and prognosis in breast cancer. A study of 1409 cases of which 359 have been followed for fifteen years. $\mathrm{Br} \mathcal{F}$ Which 359 have been foll

19 Cohen J. A coefficient of agreement for nominal scales. Education and Psychological Measurement 1960;20:37-46.

20 Beahrs OH, Hensen DE, Hutter VP, Myers MH, Eds. Manual for staging of cancer. 3rd Edn. Philadelphia: JB Lippincott Co, 1988

21 Armitage P, Berry G. I: Further analysis of qualitative data. Statistical methods in medical research. 2nd edn. Oxford: Blackwell Scientific Publications, 1987:372-4.

22 Gould VE, Koukoulis GK, Jansson DS, Nagle RB, Franke WW, Moll R. Coexpression patterns of Vimentin and glial filament protein with cytokeratins in the normal, hyperplastic and neoplastic breast. Am $\mathcal{f}$ Pathol 1990; 137:1143-55.

23 Mork C, van Deurs B, Petersen OW. Regulation of Vimentin expression in cultured human mammary Vimentin expression in cultured human

24 Sommers CL, Walker-Jones D, Heckford SE, et al. Vimentin rather than keratin expression in some hormone-independent breast cancer cell lines and in oncogene-transformed mammary epithelial cells. Cancer Res 1989;49:4258-63.

25 Domagala W, Lasota J, Bartkowiak J, Weber K, Osborn $M$. Vimentin is preferentially expressed in human breast carcinomas with low oestrogen receptor and high $\mathrm{Ki}-67$ growth fraction. Am $\mathcal{f}$ Pathol 1990;136:219-27.

26 Domagala W, Lasota J, Dukowicz A, et al. Vimentin expression appears to be associated with poor prognosis in node-negative ductal NOS breast carcinomas. $\mathrm{Am} \mathcal{f}$ in nodhol 1990;137:1299-304.

27 Domagala W, Wozniak L, Lasota J, Weber K, Osborn M. Vimentin is preferentially expressed in high-grade ductal and medullary, but not in lobular breast carcinomas. Am $f$ Pathol 1990;137:1059-64.

28 Cattoretti G, Andreola S, Clemente C, D'Amato L, Rilke F. Vimentin and p53 expression on epidermal growth factor receptor-postive, oestrogen receptor-negative breast carcinoma. Br $\mathcal{f}$ Cancer 1988;57:353-7.

29 Georgatos SD, Blobel G. Lamin B constitutes an intermediate filament attachment site at the nuclear envelope. $f$ Cell Biol 1987;105:117-25.

30 Georgatos SD, Blobel G. Two distinct attachment sites for Vimentin along the plasma membrane and the nuclear envelope in avian erythrocytes: $A$ basis for a vectorial assembly of intermediate filaments. $f$ Cell Biol torial assembly of 